\title{
FORMAÇÕES NEOLÓGICAS DO PORTUGUÊS BRASILEIRO CONTEMPORÂNEO COM SUFIXO -AÇO: UMA ABORDAGEM FUNCIONAL
}

\author{
Magda Bahia SCHLEE* \\ Thaís de Araujo da COSTA**
}

- RESUMO: À luz do aporte teórico da Linguística Sistêmico-Funcional (LSF), esta investigação visa, tomando como corpus de análise notícias de jornais e revistas digitais brasileiros publicados entre 2016 e 2018, refletir acerca do processo de formação de construções neológicas contemporâneas a partir do acréscimo do sufixo - aço a bases nominais, de origem portuguesa ou não. Tendo em vista esse propósito, fazemos primeiramente uma breve revisão bibliográfica com vistas a depreender o funcionamento e os valores semânticos atribuídos ao sufixo -aço em nossas gramáticas e em manuais linguísticos para, em seguida, verificar se os usos contemporâneos desse afixo são condizentes com os previstos nos compêndios especializados. A análise nos possibilitou depreender o funcionamento polissêmico desse afixo, bem como, em algumas situações, a sua metaforização decorrente da tensão estabelecida em diferentes estratos linguísticos, seja no plano da metafunção interpessoal, seja no da metafunção ideacional. Já no tocante ao plano da metafunção textual, propomos uma descrição do funcionamento na oração dos neologismos criados a partir do acréscimo de - aço a bases adjetivas e substantivas

- PALAVRAS-CHAVE: Linguística sistêmico-funcional. Sufixação. Neologismos.

\section{Introdução}

Em primeiro lugar, faz-se preciso destacar o caráter inovador desta pesquisa no âmbito dos estudos sistêmico-funcionais brasileiros, os quais de um modo geral concentram-se na análise da oração, do complexo oracional e da articulação estabelecida entre esses. Nesta investigação, embora, em conformidade com Halliday e Mathiessen (2014), partamos da oração como elemento central de análise, interessamo-nos pelos níveis abaixo da oração, a saber: a estruturação dos grupos que desempenham funções no estrato léxico-gramatical, a sua composição por meio de palavras e a composição destas por morfemas. Sob a ótica da metafunção ideacional, notadamente no que concerne à sua função experiencial, entende-se que esses grupos, articulados na oração por meio

\footnotetext{
Universidade do Estado do Rio de Janeiro (UERJ), Instituto de Letras. Rio de Janeiro - RJ - Brasil. magdabahia@ globo.com. ORCID: 0000-0003-3654-5849.

** Universidade do Estado do Rio de Janeiro (UERJ), Instituto de Letras. Rio de Janeiro - RJ - Brasil. araujo_thais@ yahoo.com.br. ORCID: 0000-0002-8599-3528.
} 
do sistema da transitividade, desempenham papel fundamental na construção de um modelo de representação do mundo. Nesse sentido, consideramos que as escolhas de palavras que constituem as orações e dos morfemas que as constituem também são significativas e, portanto, também produzem efeitos nesse modelo representacional. Daí buscarmos com esta reflexão compreender o funcionamento do sufixo -aço em neologismos que, formados hodiernamente, passam a constituir o léxico do português em uso no Brasil.

\section{Léxico, produtividade e criatividade}

O léxico é o conjunto de palavras em uso num dado sistema linguístico, sejam estas dicionarizadas ou não. $\mathrm{O}$ acervo lexical de todas as línguas encontra-se em constante processo de renovação. Ao passo que algumas palavras caem em desuso, tornandose arcaísmos, outras novas são ou poderiam ser criadas pelos falantes em função das necessidades comunicativas que se impõem no dia a dia. A essa possibilidade de surgimento de novos itens lexicais inerente a toda e qualquer língua nomeia-se produtividade.

A produtividade, segundo Rocha (2008), é norteada, majoritariamente, pela regularidade, dando origem a formas transparentes do ponto de vista morfológico e semântico, ou seja, tanto os elementos mórficos que as constituem são facilmente identificáveis, como os sentidos decorrentes da sua combinação são facilmente predizíveis pelos falantes. Alinhado até certo ponto a essa perspectiva, Sandmann (1991) explica que todo sistema linguístico é regido por regras que orientam tanto a análise da estrutura de unidades já integrantes do léxico quanto a formação de novas unidades, donde se justifica a transparência apontada por Rocha (2008). Sandmann acrescenta, porém, que, embora produtiva, uma regra pode estar sujeita a restrições inerentes à sua própria natureza. Esse é o caso, por exemplo, do prefixo negativo in-, que não se agrega a bases verbais ou a bases nominais de substantivos que indicam ação, diferentemente de des-, que não sofre limitação, agregando-se tanto às bases do primeiro tipo (desapertar) quanto do segundo (descontração). Uma regra pode ainda, segundo o linguista, ter a sua produtividade limitada devido a um bloqueio, fenômeno que impede a criação de uma nova unidade léxica devido à existência de uma forma correlata no sistema linguístico. Assim, diz o autor: "De vacinar se formou vacinador, de puxar, puxador e de estrangular, estrangulador, mas de roubar não se formou e provavelmente não se formará *roubador, pois o lugar já está ocupado por ladrão" (SANDMANN, 1991, p. 15, grifo do autor). Sandmann, no entanto, ressalta que o bloqueio não é uma regra geral e que pode deixar de ocorrer por diversas razões, como se dá com os pares internação e internamento e encanação e encanamento, formados em ambos os casos por palavras sinônimas derivadas do mesmo radical e registradas tanto pelo dicionário Houaiss quanto pelo VOLP ${ }^{1}$.

Disponível em: https://www.academia.org.br/nossa-lingua/busca-no-vocabulario. Acesso em: 12 mar. 2021. 
Já as irregularidades são, conforme Rocha (2008), decorrentes da permanência de uma determinada forma no léxico, o que gera a opacidade das suas unidades constituintes. As limitações apontadas por Sandmann, porém, no tocante à aplicação de uma regra de formação de unidades léxicas demonstram que a relação entre produtividade e regularidade em oposição à irregularidade não é tão evidente como pressupõe Rocha (2008), sendo mais adequado considerar, nesse caso, a existência de "um continuum, que vai da produtividade plena de alguns casos de derivação até uma produtividade bastante limitada" (SANDMANN, 1991, p. 26), e isso tanto no que diz respeito ao aspecto formal (existência de lacunas em paradigmas lexicais, como ocorre no caso do verbo roubar, do qual não deriva * roubador) quanto semântico (internação é o ato de internar, mas encanação é mais utilizado para referir-se ao conjunto de canos que ao ato de encanar). No que concerne a esse último aspecto, Sandmann ressalta ainda que a deriva semântica é um processo natural e, portanto, intrínseco à lexicalização ou idiomatização de uma palavra. Isto é, uma vez criada e incorporada ao léxico da língua por meio do uso procedido pelos falantes, ocorre o que o autor chama de desmotivação, de modo que "o todo não é mais a simples soma das partes" - caso de encanação, em que o sufixo -ção perde o sentido de ação de. Segundo o linguista, "quanto mais o conjunto dos elementos que formam uma palavra complexa se afastar ou isolar, semântica, fonológica e morfologicamente, mais perfeita será a integração e mais claramente se caracterizará a nova unidade lexical" (SANDMANN, 1991, p. 30), podendo acarretar, no que respeita à produtividade, a neutralização de restrições às regras ou o afastamento de bloqueios que lhes são impostos e, em decorrência disso, a motivação à produção de novas unidades léxicas. Assim, o autor afirma que foi, por exemplo, a deriva semântica de picareta, nome de um tipo de ferramenta, para "pessoa que usa de meios escusos para obter vantagens" - deriva que implica inclusive a adjetivação do substantivo - que neutralizou a restrição que impedia a formação do substantivo picaretagem à semelhança do que ocorre com boba $>$ bobagem, sacana $>$ sacanagem, vadia $>$ vadiagem. Essa restrição, no entanto, segundo o estudioso, continua ativa em relação a outros nomes de ferramentas, de modo que são inaceitáveis formas como *machadagem, *enxadagem, *foiçagem etc.

Esse parece também ser o posicionamento de Azeredo (2008) ao considerar que as irregularidades são decorrentes da criatividade dos falantes. Conforme esse gramático (AZEREDO, 2008, p. 399), "a produtividade é sempre sistemática e coletiva, ao passo que a criatividade é idiossincrática e particular”, o que não impede, no entanto, que um ato de criatividade gere um modelo produtivo, como ocorreu, por exemplo, com a palavra sambódromo, "criativamente formada com a terminação -(ó)dromo (=corrida), que figura em hipódromo, autódromo, cartódromo, formas que designam itens culturais da alta burguesia". O autor chama, com isso, a atenção para o surgimento, a partir da criação de sambódromo, de outras formas populares, como rangódromo, beijódromo e camelódromo, nas quais se observa um novo sentido para o radical de origem grega -(ó)dromo, que passa a significar simplesmente lugar, atestando, assim, a possibilidade de atos criativos e inicialmente irregulares tornarem-se produtivos e, 
consequentemente, regulares. Essa perspectiva vai ao encontro ainda da proposta de Câmara Jr. (1975, p. 218) para quem a produtividade de um sufixo, que lhe confere individualidade na língua portuguesa, decorre da possibilidade de palavras derivadas servirem de "modelo para a estruturação de novas palavras, fornecendo no seu elemento final um meio permanente na língua para novas derivações”.

\section{Neologismos}

Independentemente de ser fruto de um modelo previamente tomado como produtivo ou de um ato criativo que gerou um modelo produtivo, é consenso em nossas gramáticas e manuais linguísticos designar o conjunto de processos que materializam essa propriedade das línguas a partir da qual são criadas novas unidades léxicas como neologia e as formas que deles resultam como neologismos. Segundo Azeredo (2008, p. 400-402), "a introdução, assimilação e circulação de um neologismo estão sujeitas, principalmente, a fatores históricos e socioculturais", de modo que a sua vida útil é determinada pela necessidade de emprego para "designar uma ideia, um objeto, um conceito" em circulação na comunidade que o emprega. Esse critério de utilidade justifica, ainda em conformidade com o autor, o fato de "muitos neologismos durarem apenas uma temporada, enquanto outros se enraízam na língua”. A naturalização de um neologismo na língua, por sua vez, é o que muitas vezes torna difícil a tarefa de identificá-lo. Diz o autor: "uma vez posta em circulação (...), a forma neológica pode ser notada como tal por muitos usuários e não o ser por outros, e à medida que o seu emprego se repete e se expande, é possível que a consciência de neologia se torne cada vez menos clara"'.

\section{Do corpus e dos procedimentos de análise}

Neste artigo, como anunciamos, propomo-nos a analisar construções neológicas contemporâneas formadas a partir do acréscimo do sufixo -aço a bases nominais, de origem portuguesa ou não, o que quer dizer que é de nosso interesse aqui descrever as regras que atestam a produtividade atual desse sufixo em neologismos morfossintáticos, ou seja, aqueles em que se unem elementos mórficos previstos no sistema linguístico do português ou elementos deste e elementos emprestados de outras línguas, e em neologismos formados por empréstimos resultantes do contato entre diferentes comunidades linguísticas ${ }^{3}$.

\footnotetext{
O propósito deste artigo não é discorrer detalhadamente sobre o processo de neologia e os tipos de neologismos, porém um estudo mais aprofundado pode ser encontrado em Alves (1994).

3 Segundo Alves (1994), a neologia por empréstimo apresenta diferentes níveis. Num primeiro momento, o elemento estrangeiro empregado em um sistema linguístico que não é o seu original é sentido pelos falantes como externo ao léxico da sua língua receptora. Nesse caso, a grafia do sistema linguístico do qual advém o empréstimo é mantida, sendo este, nos casos em que o falante pressente que os seus interlocutores terão dificuldade de interpretá-lo, seguido
} 
Para tanto, analisaremos o emprego dessas construções em notícias de jornais e revistas digitais brasileiros publicados entre 2016 e 2018. A escolha do corpus justificase porque, em conformidade com Alves (1994), embora a língua constitua patrimônio de toda a comunidade linguística e a criatividade léxica seja um direito facultado a todos os membros dessa comunidade, é por meio dos veículos de comunicação de massa e de obras literárias que se dá a difusão dos neologismos, os quais, em função da recorrência e da produtividade do seu uso, poderão futuramente ser dicionarizados ou não, passando a incorporar oficialmente o léxico do português brasileiro. Ao elegermos textos midiáticos como corpus de análise, manifestamos, portanto, o nosso interesse em estudar a língua em uso pelos falantes do português brasileiro contemporâneo, mais especificamente as unidades léxicas recorrentes que, resultadas da criatividade do falante e da produtividade do sufixo - aço na língua, ainda não se encontram dicionarizadas. Isso porque entendemos, com Alves (1994) e Rocha (2008), que, embora a lexicografia seja um ramo de estudo respeitável, tradicionalmente o processo de dicionarização de palavras em português apresenta arbitrariedades que implicam a sua desconsideração como um instrumento científico válido para a análise linguística, tais como: a existência de palavras mortas, isto é, que não são mais utilizadas pelos falantes, a demora para inclusão de novas palavras institucionalizadas pelo uso, a distribuição das palavras em ordem alfabética, que, apesar de prática, é destituída de critério científico, e a inclusão de palavras que, mesmo institucionalizadas numa comunidade num dado momento, possuem existência fugaz ${ }^{4}$.

Por fim, cabe esclarecer que consideramos recorrentes os itens lexicais que comparecem em pelo menos três matérias diferentes no período investigado. Além disso, para verificação da pertinência da palavra tendo em vista o recorte aqui realizado, consultamos as versões digitais do Vocabulário Ortográfico da Língua Portuguesa (VOLP) e do Grande Dicionário Houaiss ${ }^{5}$, entendendo que a ocorrência em pelo menos uma dessas fontes é suficiente para que a palavra deixe de ser considerada como um neologismo recente.

Assim sendo, com vistas a atender a esse objetivo, organizamos o presente artigo em três partes. Na primeira, faremos uma breve revisão bibliográfica com vistas a depreender o funcionamento e os valores semânticos atribuídos ao sufixo -aço em nossas gramáticas e manuais linguísticos. $\mathrm{Na}$ segunda, procederemos à análise do corpus, visando verificar se os usos contemporâneos desse afixo são condizentes com os previstos nos compêndios especializados, ao mesmo tempo em que propomos uma

da sua tradução literal. A autora ressalta que, enquanto tomado como um estrangeirismo, o elemento não integra o léxico da língua receptora e que o seu processo de integração pode se manifestar por meio da adaptação gráfica, morfológica ou semântica, ainda que se observe frequentemente a concorrência entre a grafia original do item lexical e a forma aportuguesada, como ocorre, por exemplo, com shampoo e xampu. Em outros casos, porém, o emprego recorrente de um estrangeirismo pode fazer com que a sua forma original passe a ser considerada como parte integrante do acervo lexical, como ocorre com lingerie, jeans e show, por exemplo.

4 Deve-se lembrar, contudo, que a ordem alfabética não é a única possibilidade de ordenação dos verbetes em um dicionário. Há outras possibilidades, como a que encontramos nos dicionários de caráter onomasiológico.

5 Disponível em: https://houaiss.uol.com.br/pub/apps/www/v3-3/html/index.php\#0. Acesso em: 12 mar. 2021. 
reflexão a respeito desses usos a partir do aporte teórico da LSF. Por fim, na terceira, exporemos as conclusões a que chegamos a partir da análise depreendida.

\section{Revisão bibliográfica}

Para esta revisão, consultamos gramáticos e linguistas filiados a diferentes perspectivas teóricas, quais sejam: Câmara Jr. (1975), Sandmann (1987, 1988, 1991), Cunha \& Cintra (2001), Monteiro (2002), Bechara (2009), Azeredo (2008), Basílio (2011), Rocha (2008) e o capítulo sobre Derivação Sufixal do Volume VI do trabalho coletivo intitulado Gramática do Português Culto Falado no Brasil (MARONEZE; CARDOSO; PISSOLATO, 2015). Todos sem exceção classificaram semanticamente o sufixo -aço como aumentativo. Alguns, porém, apresentaram, além desse, outros sentidos. Esse é o caso de Bechara (2009, p. 357), que nos explica, em defesa do seu ponto de vista, que

Os sufixos dificilmente aparecem com uma só aplicação; em regra, revestem-se de múltiplas acepções e empregá-los com exatidão, adequando-os às situações variadas, requer e revela completo conhecimento do idioma. Ao lado dos valores sistêmicos, associam-se aos sufixos valores ilocutórios intimamente ligados aos valores semânticos das bases a que se agregam, dos quais não se dissociam.

Essa é também a perspectiva defendida por Monteiro (2002), para quem a possibilidade de um mesmo sufixo apresentar mais de um conteúdo significativo configura-se como um caso de polissemia, e não de homonímia, como alguns linguistas defendem, o que ocorreria se tivéssemos diferentes sufixos que se realizassem da mesma forma e com diferentes significados ${ }^{6}$.

No que concerne especificamente ao sufixo - aço/-aça, Bechara esclarece ainda que é empregado para "formação de nomes de ação ou resultado de ação, estado, qualidade, semelhança, composição, instrumento, lugar” (BECHARA, 2009, p. 358), apresentando como exemplo o substantivo vidraça, e para "significar abundância, aglomeração, coleção", como ocorre em chumaço. Mesmo ao classificá-lo dentre os sufixos indicadores de grau, Bechara o arrola não só dentre os sufixos aumentativos, como ocorre em ricaço, barcaça e copaço, mas também diminutivos ao lado de -iço e -iça, como em: fumaça, caniço e nabiça (BECHARA, 2009, p. 359), destacando que nesse caso os nomes formados podem ser empregados pejorativa ou afetivamente. Bechara ainda observa que a "noção de aumento corre muitas vezes paralela à de

6 Santos (2010), com base nos trabalhos de Malkiel e Pharies em relação ao sufixo -azo do espanhol, apresenta uma interessante discussão sobre essa questão a partir da perspectiva diacrônica. Como o objetivo desta pesquisa é fazer uma análise sincrônica do funcionamento do sufixo -aço no português, julgamos que adotar a perspectiva de Monteiro (2002) é mais condizente com esse propósito. Essa discussão, porém, será retomada mais adiante. 
coisa grotesca e se aplica às ideias pejorativas" (BECHARA, 2009, p. 357), como em mulheraça, e que, em determinadas situações, "alguns sufixos assumem valores especiais (por exemplo florão não se aplica em geral a flor grande, mas a uma espécie de ornato de arquitetura), enquanto outros perdem o seu primitivo significado, como carreta, camisola" (BECHARA, 2009, p.357).

O valor depreciativo é citado também por Câmara Jr. (1975), Cunha e Cintra (2001) e Monteiro (2002). Esse último acrescenta que o sufixo -aço "realiza-se como [aço], [iço] ou [uço]" e pode apresentar diversas acepções, dentre as quais destaca: "intensidade (ricaço), grandeza (mulheraça), pequenez (caniço), tendência, possibilidade (quebradiço), depreciação (dentuça)" (MONTEIRO, 2002, p. 167). Câmara Jr. (1975, p. 227), por seu turno, destaca que a formação aumentativa é esporádica e "frisa sempre uma intenção fortemente pejorativa, podendo-se dizer que é exclusivamente um recurso para a linguagem afetiva (insultuosa)". No entanto, os exemplos apresentados para o sufixo -aço, a saber: barbaça e mestraço, não parecem confirmar o que diz o linguista.

Já Azeredo (2008, p. 463-464) postula que esse sufixo exprime variação de grau e/ou de aspecto do sentido da base, podendo adicionar uma referência à sua dimensão física ou um juízo de valor, como em filmaço. O juízo de valor positivo, isto é, aquele que exprime a ideia de excelência, também é referido por Basílio (2011), que afirma ser esse o principal emprego do sufixo -aço, como ocorre em golaço.

Para Sandmann $(1987,1988,1991)$, além dos significados aumentativo (barcaça), melhorativo ou pejorativo (mulheraça) ${ }^{7}$ e de intensidade (ricaço), esse sufixo expressa também o significado de resultado de ação enérgica, golpe, pancada, no qual vemos a sobreposição com o sentido de intensidade, como ocorre em pataço, munhecaço e joelhaço, para enfatizar o sentido de que se trata de um golpe ou pancada forte. Com esse significado, o Dicionário Houaiss apresenta ainda os seguintes verbetes: chifraço (sinônimo de chifrada, golpe com chifres), chicotaço (chicotada forte, golpe com chicote) e canivetaço (sinônimo de canivetada, golpe com canivete), entre outros. O autor aponta também o sentido de toque ou manifestação ruidosa, citando como exemplo os vocábulos buzinaço, panelaço e apitaço, sobre os quais discorreremos adiante, acrescentando que nesses casos a ideia de intensidade persiste (SANDMANN, 1987, 1991).

Filiando-se de certo modo ao pensamento de Câmara Jr. (1975), Rocha (2008, p. 218) afirma que "toda formação gradual complexa expressa necessariamente afetividade e, em alguns casos, aumento ou diminuição de tamanho". Daí propor que os chamados sufixos aumentativos e diminutivos sejam designados como sufixos avaliativos, os quais se organizam em três grupos, conforme a sua natureza:

1) Sufixos subjetivos - são aqueles que expressam a subjetividade do falante (carinho, amor, educação), e não apenas afetividade em relação a um referente específico, como em: "Podem me dar uma licencinha?", "Filhão, dá um abraço no paizão!".

Sobre o substantivo mulheraça, diz Sandmann (1987, p. 58): "Em mulheraço/mulheraça a semântica pode ser de apreço ('mulher muito atraente') ou a conjugação do aumento com a da conotação de apreço ('mulher alta e bonita') ou do desapreço ('mulher alta e desajeitada')". 
2) Sufixos valorativos - são aqueles que expressam um julgamento de valor em relação ao referente, como em: "Ele comprou um apartamentaço!".

3) Sufixos dimensionais - são aqueles que expressam a ideia de tamanho aumentativo, como em "Você viu o narigão daquele homem?", ou diminutivo, como em "Ele mora naquela casinha da esquina".

Notemos que a construção com sufixo - aço comparece apenas no tipo 2, sufixos valorativos, o que aproxima o ponto de vista de Rocha daquele defendido por Azeredo (2008) e Basílio (2011).

Além disso, deve-se esclarecer que a inversão proposta pelo autor, que coloca a afetividade como anterior ao aumento ou à diminuição do tamanho de um substantivo, é o que justifica a sua consideração, diferentemente de todos os outros teóricos anteriormente mencionados, do chamado grau avaliativo como um caso de flexão, e não de derivação.

A despeito de não concordarmos com essa última colocação defendida pelo linguista, uma vez que entendemos que os sufixos por ele elencados têm potencial criativo de novas palavras, caracterizando-se assim como derivacionais, e não flexionais, interessam-nos em sua reflexão dois pontos específicos. São eles: a distinção entre um valor subjetivo e afetivo, entendido como emotivo, e a constatação de que os diversos sentidos apresentados pelos sufixos tradicionalmente classificados como aumentativo ou diminutivo apresentam uma carga afetivo-emotiva que lhes é inerente e que, a nosso ver, está relacionada aos valores ilocutórios a que se refere Bechara (2009), os quais lhes são atribuídos nas diferentes situações comunicativas em que são empregados.

Resta observar ainda que, no capítulo dedicado à derivação sufixal da Gramática do Português Culto Falado no Brasil, embora o sufixo -aço seja arrolado dentre os principais sufixos aumentativos, não são apresentados exemplos, o que nos sugere que não houve comparecimento relevante nos corpora analisados. Os corpora em questão são compostos de entrevistas realizadas no âmbito do Projeto NURC (Norma Urbana Culta) em cinco capitais brasileiras - Porto Alegre, São Paulo, Rio de Janeiro, Salvador e Recife-, entre as décadas de 70 e 90 do século XX, com informantes com nível superior completo nascidos nessas capitais, em três situações específicas de comunicação: elocuções formais (aulas), diálogos entre documentador e informante e entre dois informantes. Essa ausência é, pois, para nós significativa, visto que parece, a uma primeira vista, corroborar a hipótese de relação intrínseca entre a carga afetivo-emotiva inerente aos sufixos designados por Rocha (2008) como avaliativos e a situação de uso.

No que diz respeito às bases a que se agrega o sufixo -aço, Azeredo (2008) pontua que ele deriva substantivos de outros substantivos. Já Cunha e Cintra (2001) acrescentam que, mais raramente, também pode se prender a radicais de adjetivos.

Com base no levantamento realizado, formulamos o quadro a seguir, que visa sintetizar os aspectos até aqui apresentados no que concerne ao uso do sufixo - $a c ̧ o$ : 
Quadro 1 - Síntese da revisão bibliográfica

\begin{tabular}{|c|c|c|}
\hline \multirow{4}{*}{$\begin{array}{c}\text { Critério } \\
\text { morfológico }\end{array}$} & \multicolumn{2}{|l|}{ A - Realização } \\
\hline & \multicolumn{2}{|l|}{ [aço] [aça] [iço] [iça] [uço] [uça] } \\
\hline & \multicolumn{2}{|l|}{ B - Forma resultante e base a que se agrega } \\
\hline & \multicolumn{2}{|c|}{$\begin{array}{l}\text { - substantivos formados a partir de substantivos (copo > copaço) } \\
\text { - adjetivos formados a partir de adjetivos (rico }>\text { ricaço) } \\
\text { - adjetivos formados a partir de substantivos (dente }>\text { dentuço) } \\
\text { - substantivos formados a partir de verbos (cansar }>\text { cansaço) }\end{array}$} \\
\hline \multirow{17}{*}{$\begin{array}{l}\text { Critério } \\
\text { semântico }\end{array}$} & Valor semântico & Exemplo \\
\hline & 1) grau aumentativo (dimensão física) & copaço, mulheraça \\
\hline & 2) grau diminutivo (dimensão física) & fumaça, caniço, nabiça \\
\hline & $\begin{array}{l}\text { 3) abundância, aglomeração, coleção, } \\
\text { conjunto }\end{array}$ & Chumaço \\
\hline & 4) ação/ resultado de ação & assanhaço, cansaço, inchaço ${ }^{8}$ \\
\hline & $\begin{array}{l}\text { 5) resultado de ação enérgica, golpe ou } \\
\text { pancada }\end{array}$ & pataço, munhecaço, joelhaço \\
\hline & 7) qualidade & barbaça, melgaço ${ }^{9}$ \\
\hline & 8) semelhança & rosaça, brancaço, pardaço ${ }^{10}$ \\
\hline & 9) composição & Vidraça \\
\hline & 10) instrumento & --- \\
\hline & 11) lugar & --- \\
\hline & $\begin{array}{l}\text { 12) juízo de valor pejorativo ou } \\
\text { depreciativo }\end{array}$ & mulheraça, dentuço \\
\hline & $\begin{array}{l}\text { 13) Juízo de valor positivo/ melhorativo / } \\
\text { excelência }\end{array}$ & $\begin{array}{c}\text { mestraço, filmaço, golaço, } \\
\text { apartamentaço }\end{array}$ \\
\hline & 14) intensidade & Ricaço \\
\hline & 15) estado, tendência, possibilidade & quebradiço $^{11}$ \\
\hline & 16) subjetivo & --- \\
\hline & 17) toque, manifestação ruidosa & buzinaço, apitaço, panelaço \\
\hline
\end{tabular}

Fonte: Elaboração própria.

8 Embora não sejam apresentados exemplos nos compêndios analisados para o valor semântico em questão, Santos (2010), ao analisar os verbetes com - aço presentes no Dicionário Houaiss, destaca dentre eles assanhaço e cansaço, afirmando ser o primeiro de base nominal e o segundo de base verbal. Apesar de assanhaço poder ser interpretado como ação ou resultado de se assanhar, assim como cansaço é interpretado como ação ou resultado de se cansar e inchaço como ação ou resultado de inchar, o Dicionário Houaiss confirma o posicionamento de Santos apresentando assanhaço como palavra derivada de assanho, que, por sua vez, seria derivada de sanha. A autora inclui ainda nesse significado os substantivos panelaço e buzinaço, com o que, como será visto adiante, discordamos.

9 Não foram encontrados exemplos nos compêndios analisados que apresentam esse valor. Barbaça-barba comprida e vasta, segundo o Dicionário Houaiss - foi extraído de Câmara Jr., embora ele assim não o classifique. Já melgaço foi extraído diretamente do Dicionário Houaiss, no qual é apresentado como sinônimo de louro (característica do "que tem a cor amarelo-tostada ou entre o dourado e o castanho-claro") e de arruivado (característica do "que apresenta um tom mais ou menos ruivo").

10 Os exemplos são de Santos (2010). Não foram encontrados exemplos nos compêndios analisados.

11 Embora sincronicamente possamos analisar como formado a partir do acréscimo do sufixo -iço ao radical do adjetivo quebrado, o Dicionário Houaiss apresenta como um espanholismo (quebradizo) que ingressou na língua portuguesa no século XIII. 
O quadro acima nos permite tecer mais cinco comentários acerca da abordagem dispensada ao sufixo - aço nos compêndios analisados. Em primeiro lugar, destacamos a possibilidade de esse sufixo apresentar diferentes sentidos quando agregado a uma mesma base. Esse é o caso, por exemplo, de mulheraça, arrolada por Bechara (2009) como exemplo de valor depreciativo, por Monteiro (2002) como exemplo de valor aumentativo (dimensão física, grandeza) e por Sandmann (1987) como de valor depreciativo, melhorativo e aumentativo. É, pois, a situação comunicativa que nos permitirá nesse caso depreender o significado atribuído à base pelo afixo.

Em segundo lugar, é preciso considerar também que, em certas situações, em consonância com o que propõe Bechara (2009), poderá haver sobreposição de sentidos, como ocorre em dentuço(a), adjetivo no qual a ideia de grandeza da dimensão física dos dentes está associada a um valor pejorativo, grotesco. Tal sobreposição evidencia nesse caso a anterioridade proposta por Rocha (2008) da carga afetivo-emotiva em relação à noção de tamanho. Porém, como podemos constatar a partir da análise do Quadro I, ela não ocorre em relação a todos os sentidos arrolados, como podemos observar em vidraça, chumaço, fumaça, caniço (sentido literal), nabiça etc.

Em terceiro lugar, observemos que, embora não seja dito de forma explícita, o valor de intensidade ocorre sozinho apenas quando a palavra base é um adjetivo (ricaço $=$ muito rico), todos os outros valores semânticos ocorrem quando o sufixo se agrega a uma base substantiva, seja para formar outro substantivo, seja para formar, ainda que mais raramente, um adjetivo (dentuço), ou a uma base verbal.

Em quarto lugar, no que diz respeito às categorias das palavras bases a que o sufixo - aço pode-se associar, devemos acrescentar, com Santos (2010), que, além das bases substantivas e adjetivas, ele também pode agregar-se a bases verbais para formar substantivos, como ocorre em: cansar > cansaço, inchar > inchaço.

Por fim, um quinto e último comentário: todos os itens lexicais elencados no exemplário dos compêndios analisados, com exceção de apitaço $^{12}$, filmaço e apartamentaço, encontram-se dicionarizados. Tal fato é de extrema relevância para se compreender o tipo de estudo morfológico depreendido não só por gramáticos tradicionais, mas também por boa parte dos linguistas filiados a diferentes perspectivas teóricas: estudo este voltado sobretudo para a classificação e a depreensão de morfemas que constituem palavras já conhecidas na língua, e não para o potencial criativo desses morfemas e para o aspecto produtivo das regras que subjazem ao seu emprego, isto é, para a língua em uso, como nos propomos a fazer aqui.

\section{Análise do corpus}

No corpus analisado, encontramos tanto neologismos adjetivos quanto substantivos formados a partir do acréscimo do sufixo - aço, os quais comparecem por vezes entre

12 Embora apitaço não esteja registrado nos dicionários brasileiros Houaiss e Aulete, encontra-se no dicionário português Priberam. 
aspas, por vezes incorporados aos textos sem nenhuma demarcação. Como vimos em Azeredo (2008), além de construções neológicas poderem ser mais facilmente identificadas por uns falantes e menos por outros, a sua naturalização no léxico torna a sua identificação cada vez mais difícil. A consciência neológica em relação a um determinado item lexical é chamada por Alves (1994, p. 83) de sentimento de neologia. A autora esclarece ainda que tal sensação "traduz-se graficamente por processos visuais como aspas, maiúsculas e itálico, que visam realçar o resultado da criatividade lexical". Uma outra forma de destacar essa criatividade é, ainda segundo a autora, o emprego de expressões metalinguísticas, como "chamado, dito". Em outras palavras, o emprego dessas marcas linguísticas expressa a intenção do falante de sinalizar ora que aquela palavra não pertence oficialmente ao léxico da língua portuguesa, no caso dos neologismos fonológicos e morfossintáticos, ora que o sentido da unidade léxica empregada naquele contexto passou por uma transformação, ou seja, que a unidade não está sendo empregada no seu sentido literal, no caso dos neologismos semânticos. Já a ausência de aspas parece sugerir um grau maior de naturalização e aceitação do emprego da forma neológica possivelmente devido ao seu uso, não só recorrente, mas também há mais tempo na língua.

No que diz respeito aos sentidos associados pelo sufixo às bases às quais se agrega, observamos, em consonância com Bechara (2009) e Monteiro (2002), certa diversidade, conforme passaremos a especificar a seguir, em função da situação comunicativa em que os nomes derivados foram empregados.

\section{Adjetivos [Adj $\rightarrow \mathbf{A d j}_{\text {+aço }}$ lem orações relacionais}

O sufixo -aço forma adjetivos quando associado a uma base adjetiva, integrando grupos nominais que funcionam, em orações que expressam processos relacionais intensivos, como atributos qualificativos do portador. No corpus analisado, foram depreendidas três ocorrências. São elas: 
Quadro 2 - Neologismos formados a partir de bases adjetivas

1) Leão-marinho volta ao mar após quatro dias 'perdidaço' em cidade $(R 7,5 / 9 / 2018)$

2) - Fui fazer teste para ser um dos integrantes da boy band, mas, diferentemente dos outros atores que estavam lá, eu fui logo dispensado pelo diretor. Fiquei boladaço, achando que tinha mandado malzão. Não deu duas horas e me ligaram para voltar no dia seguinte. Quando abri o texto, entendi tudo. Era Felipe, um DJ vingativo que não sabe lidar com perdas e frustrações. Não sei de onde vem essa minha cara de mau. Na vida, sou do tipo que perde a piada, mas não o amigo - diz o artista, que só fez um mocinho na telinha, em "Amor e revolução" (2011). (Extra, 16/8/2018)

3) O cansaço de Marcos Martins, piloto do avião que caiu em Santos (SP), em 13 de agosto de 2014, matando o então candidato presidência do PSB e ex-governador de Pernambuco, Eduardo Campos, e outras seis pessoas, foi um dos fatores que contribuiu para a tragédia, que teve uma sequência de falhas humanas; o cansaço do piloto foi identificado pelo seu tom de voz; poucos dias antes do acidente, o próprio Martins já havia dito, em redes sociais, que estava "cansadaço". (Brasil 247, 19/1/2016)

Fonte: Elaboração própria.

A primeira ocorrência comparece na manchete de uma notícia publicada no canal de notícias R7; a segunda, na transcrição da fala de um artista jovem durante uma entrevista publicada no jornal Extra, ambas em 2018; e a terceira, no corpo de uma notícia de 2016 como transcrição parcial de uma postagem em redes sociais do piloto do helicóptero em que viajava o então candidato à presidência Eduardo Campos.

No primeiro caso, poderíamos subentender o verbo ficar em "após ficar quatro dias perdidaço em cidade", de modo a se identificar que o adjetivo destacado é um atributo do sujeito elíptico "leão-marinho". A informação que aqui nos interessa poderia, então, ser sintetizada na seguinte oração:

$\begin{array}{ccccc}\text { Leão-marinho } & \text { ficou } & \text { perdidaço } & \text { em cidade } & \text { por quatro dias } \\ & \text { Processo } & \text { Atributo } & \text { Circunstância } & \text { Circunstância } \\ \text { Portador } & \text { relacional } & \text { qualificativo } & \text { de lugar } & \text { de tempo } \\ & \text { intensivo } & \text { and }\end{array}$

No segundo caso, o adjetivo boladaço funciona como atributo do sujeito desinencial $e u$, que tem como referente o artista jovem entrevistado.

$\begin{array}{ccc}\text { [Eu] } & \text { Fiquei } & \text { boladaço } \\ \text { Portador } & \begin{array}{c}\text { Processo relacional } \\ \text { intensivo }\end{array} & \text { Atributo qualificativo }\end{array}$

Já no terceiro caso, o adjetivo cansadaço ocorre na transcrição de um discurso indireto feito pelo jornalista a partir de uma fala do piloto do avião, integrando, assim, 
uma oração projetada que realiza o papel de verbiagem em forma de relato de uma oração verbal e tem o mesmo sujeito desta, como podemos ver a seguir.

\begin{tabular}{|c|c|c|c|c|}
\hline $\begin{array}{c}\text { O próprio } \\
\text { Martins }\end{array}$ & já & havia dito, & $\begin{array}{l}\text { em redes } \\
\text { sociais, }\end{array}$ & que estava "cansadaco" \\
\hline Dizente & $\begin{array}{c}\text { Circunstância } \\
\text { de tempo }\end{array}$ & $\begin{array}{l}\text { Processo } \\
\text { verbal }\end{array}$ & $\begin{array}{c}\text { Circunstância de } \\
\text { lugar }\end{array}$ & Relato \\
\hline
\end{tabular}

Porém, como nos interessa apenas a oração em que ocorre a forma neológica, vamos transformar o relato em discurso direto:

\section{Eu [Martins]}

Portador

\section{estou}

Processo relacional

intensivo cansadaço

Atributo qualificativo

Do ponto de vista morfológico, em perdidaço, o sufixo -aço foi acrescido ao radical do adjetivo perdido; em boladaço, ao radical do adjetivo bolado, que, embora seja restrito à linguagem coloquial, encontra-se registrado no Dicionário Houaiss com a acepção de "surpreso e confuso com determinada atitude ou reação de outrem" e "aborrecido, chateado, amolado", dentre outros que não se referem ao contexto em questão; e em cansadaço, ao radical do adjetivo cansado.

É interessante observar que, no primeiro caso, as aspas demarcam a presença de uma espécie de corpo estranho na manchete da notícia, na qual se espera encontrar o registro culto da modalidade escrita da língua, ao passo que na transcrição da fala do jovem artista a ausência das aspas sinaliza uma maior recorrência e aceitação dessa palavra na modalidade oral informal. Já, no terceiro caso, o seu emprego se deve à necessidade de demarcar aquele significante como pertencente ao discurso do piloto, embora possamos também considerar uma sobreposição de empregos: demarcação simultânea de palavra alheia e de unidade léxica restrita ao uso coloquial, isto é, não pertencente oficialmente ao acervo do português brasileiro.

No que concerne ao sentido acrescido pelo sufixo, nota-se nos três casos a intensificação do sentido básico, sentido este arrolado, como vimos, por Monteiro (2002). Assim, estar perdidaço significa estar muito perdido; estar boladaço, muito bolado; e estar cansadaço, muito cansado.

Em suma, a análise da transitividade empreendida nas orações em que figuram os adjetivos em - aço formados a partir de base adjetiva evidenciou que, nas três ocorrências, esses adjetivos assumem a função semântica de atributo qualificativo em orações relacionais, que são comumente usadas para representar seres no mundo em termos de suas características e identidades.

Outro aspecto digno de nota é o fato de esses adjetivos em -aço figurarem sempre como sintagmas autônomos e nunca como sintagmas internos dentro de outra função 
semântica, o que daria margem a construções, de certo modo, agramaticais, como se percebe no exemplo: * O perdidaço aluno era muito gentil com os colegas. Queremos crer que isso se deve a dois aspectos semânticos distintos. O primeiro deles diz respeito ao fato de os adjetivos-base que deram origem às formações com - aço indicarem estados ou qualidades eventuais e não constantes dos termos a que se referem. O segundo está diretamente ligado ao valor de intensificação expresso pelo sufixo, que só ocorre quando os adjetivos figuram autonomamente como sintagmas.

\section{Substantivos $\left[\mathbf{S} \rightarrow \mathbf{S}_{\text {+aco }}\right]$}

\section{Juízo de valor positivo/ melhorativo/ de excelência em orações materiais}

O sufixo - aço é acrescido a uma base substantiva para formar substantivos, expressando, como pontuamos anteriormente, diferentes valores semânticos, dentre eles o aspecto valorativo, mencionado por Azeredo (2008), Rocha (2008) e Basílio (2011), que é empregado para ressaltar a qualidade de algo.

No corpus analisado, encontramos as formas neológicas festaço, discaço e filmaço, as quais foram formadas, respectivamente, a partir dos substantivos festa, disco e filme e funcionam como termo nuclear de grupos nominais ou preposicionais que integram orações materiais para expressar juízo de valor positivo, melhorativo ou de excelência, como pode ser constatado adiante:

Quadro 3 - Neologismos formados a partir de bases substantivas (excelência)

1) Marcinho completa a lista dos artistas que sobem ao palco no Réveillon Colosso 2017. O cearense promete muita diversão e animação durante seu show. Mas o "festaço" não acaba por aí, pois a data merece uma emocionante queima de fogos para coroar a chegada do novo ano. (O Povo, 28/12/2016)

2) Sem os mesmos exageros de singles anteriores, Christina não entrega um discaço, mas dá para dizer que é uma retomada na carreira. (O Globo, 15/6/2018)

3) 'A chegada' transforma alfabetização de ETs em filmaço tenso e atordoante (G1, 24/11/2016)

Fonte: Elaboração própria.

Em 1), a forma neológica é termo nuclear do grupo nominal que funciona como termo afetado do processo material transformativo expresso pelo verbo ergativo acabar.

O festaço

Afetado não acaba

Processo material transformativo por aí

Circunstância de lugar

Em 2), o neologismo discaço é termo nuclear do grupo nominal que funciona como meta do processo material expresso pelo verbo entregar, no qual se amalgamam os 
valores transformativo e criativo, já que, nesse contexto, poder-se-ia acrescentar um beneficiário recebedor no sentido de entregar literalmente algo a alguém (ao público, por exemplo), ao mesmo tempo em que se subentendem os processos criativos que envolvem a gravação de um disco (compor, arranjar, gravar, editar etc.), de modo que Christina não é somente uma entregadora do disco, mas também a responsável pela sua criação.

\section{Christina}

Ator não entrega

Processo material transformativo e criativo um discaço

Meta

Em 3), o neologismo filmaço é núcleo de um grupo preposicional que funciona como atributo resultativo do processo material transformativo.

'A chegada'

transforma

Processo material

Ator

transformativo

alfabetização de ETs

Meta

\section{em filmaco tenso e atordoante}

Atributo resultativo

A partir da análise dos casos acima, é possível observar ainda que os neologismos que designam excelência podem comparecer tanto em orações de polaridade positiva, como no exemplo (3), quanto de polaridade negativa, como no exemplo (2), no qual a excelência do disco apresentado ao público e à crítica de um modo geral pela cantora Christina Aguilera é negada. É digna de nota também a posição nuclear que os substantivos em - aço ocupam nos sintagmas nominais de que fazem parte. Queremos crer que isso se deve à força semântica que o sufixo assume, tanto no que se refere à intensificação quanto à expressão de juízo de valor. Ou, em outras palavras, é a força semântica do sufixo - aço que determina a posição que os termos com ele formados ocuparão no sintagma.

\section{-aço como elemento gramatical denotador de modalidade}

Halliday e Mathiessen (2014) postulam que, sob a ótica da metafunção interpessoal, a oração é concebida como uma troca. Conceber a oração como troca pressupõe considerar a linguagem enquanto possibilidade de interação com e entre pessoas em diferentes situações comunicativas. No processo de interação, os indivíduos, desenvolvendo diferentes papéis sociais, os quais são determinados por condições específicas (sociais, econômicas, hierárquicas etc.), negociam formas de se relacionar com o outro, expressando opiniões e atitudes, com vistas a dar ou a solicitar informações ou bens e serviços. Na primeira situação - dar ou receber informações -, o produto da troca é a própria linguagem; ao passo que, na segunda - dar ou receber bens e serviços -, 
a linguagem é utilizada com o objetivo de exercer influência sobre o comportamento de outrem. Em um caso e em outro, com vistas a alcançar o seu propósito interacional, os indivíduos mobilizam recursos léxico-gramaticais disponíveis no sistema linguístico que denotam, dentre outros, polaridade e modalidade.

A polaridade, segundo os autores, é expressa pela oposição afirmativo/negativo e pode ser encontrada em todos as línguas, constituindo normalmente a primeira a forma não marcada, enquanto a segunda é percebida por algum elemento adicional, como o advérbio não em português. Halliday e Mathiessen (2014) ressaltam, contudo, que essa oposição não é significada de forma transparente no sistema linguístico, havendo, pois, dependência da situação comunicativa para que seja depreendido o que é sugerido simbolicamente.

$\mathrm{Na}$ seção anterior, vimos que neologismos com -aço formados a partir de substantivos para expressar juízo de valor podem comparecer tanto em orações de polaridade afirmativa quanto de polaridade negativa. $\mathrm{O}$ mesmo poderia ser dito a respeito das construções neológicas formadas a partir de adjetivo para expressar intensidade, como em Eu não fiquei boladaço. Parece-nos, porém, que, em ambos os casos, a polaridade negativa representa uma ruptura de paradigma, ou seja, não são usualmente empregadas por falantes de português brasileiro e ocorrem em situações excepcionais. No exemplo que comparece em nosso corpus (Christina não entrega um discaço), a negação parece manifestar uma quebra de expectativa possivelmente projetada tendo em vista a qualidade dos demais álbuns gravados pela cantora, ou seja, esperava-se que ela entregasse um discaço, mas isso não ocorreu.

Embora não tenha sido nosso propósito fazer uma coleta de dados exaustiva, nos exemplos analisados, podemos observar que as orações em que essas formas neológicas comparecem têm predominantemente polaridade positiva. A nosso ver, tal fato se justifica em função do objetivo comunicativo colocado em questão ao se mobilizar esse tipo de construção neológica com - $a c ̧ o$, a saber: avaliar positivamente uma ideia, quando associado a uma base substantiva, ou intensificar uma característica expressa pelo lexema, quando associado a uma base adjetiva. Nesses casos, um valor negativo até comparece, mas esse normalmente está associado ao lexema a que se agrega o sufixo, de modo que a oração assume forma positiva, como em Ele é feiaço (não é bonito) ou O goleiro engoliu um frangaço (não defendeu uma bola fácil), e não à oração.

Ainda à luz do pensamento de Halliday e Mathiessen (2014), devemos considerar a polaridade como um continuum no qual se situam os atos de fala (declarações, reações, opiniões) e que tem como extremos opostos os polos positivo e negativo e como níveis intermediários a modalidade. A modalidade, definida pelos autores como "uma região de incertezas entre o sim e o não" (HALLIDAY; MATHIESSEN, 2014, p. 176), diz respeito à forma assumida pelo texto, numa dada situação comunicativa, a fim de se alcançar um propósito específico. Ao se analisarem as diferentes formas possíveis para manifestar uma mesma ideia, é possível depreender inúmeros recursos empregados pelos falantes para assumir posição frente a um ser, objeto ou situação, expressando a sua opinião. Isso significa que a escolha dos recursos léxico-gramaticais que irão 
constituir os nossos enunciados é determinada por fatores contextuais, como a relação estabelecida entre os participantes da situação, a imagem que têm de si, do outro e do objeto do dizer e a distância social existente entre eles. Possivelmente foi a percepção dessa característica presente em determinadas situações de uso que levou Rocha (2008) a postular a anterioridade do significado de afetividade em relação aos outros valores apresentados pelos sufixos tradicionalmente classificados como aumentativo. A nosso ver, todavia, a configuração do sufixo - aço como recurso gramatical que manifesta modalidade está restrita aos casos anteriormente analisados, ou seja, às situações em que se agrega a uma base adjetiva para expressar intensidade e a uma base substantiva para expressar juízo de valor, além daqueles em que expressa grandeza física, revelando assim o julgamento ou ponto de vista do falante sobre o objeto do seu dizer. Por fim, cabe anunciar que tal uso, como veremos adiante, configura-se como aquilo que, do lugar da LSF, chamamos de metáfora gramatical interpessoal.

\section{Ação coletiva e manifestação em orações materiais, relacionais e existenciais}

Quadro 4 - Neologismos formados a partir de bases substantivas (ação coletiva/manifestação)

1) Em novembro de 2015, Nathalia Moura Aragão, de 20 anos, e Iago da Costa Aragão, de 24, realizaram o sonho de selar a união amorosa em um casamento comunitário em Santa Cruz. Assim como eles, que disseram "sim" em um grupo de 1.200 pessoas, outras centenas de apaixonados terão a oportunidade de trocar alianças, sem qualquer custo, na edição deste ano do "casamentaço" organizado pela Usina Comunitária CSA. (Extra, 8/10/2016)

2) Fiéis contribuem com Círio comprando artigos religiosos e adesivando veículos, no AP Visando angariar fundos para o festejo, uma equipe da Diocese da capital realiza adesivaço e venda de artigos religiosos em frente à Catedral de São José, no Centro. (G1, 8/9/2018)

3) Atividades de 'mamaço' fecham ações do Agosto Dourado no Centro-Oeste Paulista (G1, 31/1/2018).

4) 'Toplessaço' recebe apoio de banhistas na praia de Ipanema ( $O$ Globo, 4/11/2017)

5) Internautas fazem 'vomitaço' contra Temer e PMDB nas redes sociais (Folha de São Paulo, $11 / 5 / 2016)$

6.1) Decreto que acaba com rotulagem de transgênicos é alvo de 'twitaço' ( $O$ Globo, 30/8/2017)

6.2) O PT já anunciou que fará um "tuitaço" com a hashtag \#HaddadÉLula às 15h13 desta terça (Gazeta do povo, 11/9/2018)

6.3) No Twitter, há um "twittaço" marcado para as $18 \mathrm{~h}$ com a hashtag \#ConceicaoEvaristoNaABL. (O Globo, 29/8/2018)

7) Metrô Botafogo, no Rio de Janeiro, recebe mais um "lulaço" (Revista Fórum, 5/9/2018) 
8.1) Eu emprestaria minha página do FB para postagem automatizadas massivas, em uma ação ativista! E já fiz isso em 2015, quando o Meu Rio lançou o Compartilhaço, um aplicativo desenvolvido por eles e que sincronizava milhares de páginas para vocalizar causas públicas e importantes. (Revista Fórum, 30/3/2018)

8.2) A partir do dia 25 de maio, um "Compartilhaço" vai chamar a atenção de quem passa pela Avenida Brasil, com frases adaptadas da Declaração Universal dos Direitos Humanos DUDH, que estarão expostas em faixas de três passarelas da Avenida. (Brasil 247, 16/9/2018)

8.3) \#DemocraciaSim suspende compartilhaço após ataque de hackers (Catraca livre, 25/9/2018)

9) Universitários fazem ‘beijaço' contra suposto ato de homofobia na frente de bar em Boa Vista (O Globo, 24/10/2017)

10) Festa de réveillon de Copacabana terá 'abraçaço' para 2018 (Extra, 25/12/2017)

11) O panelaço, o buzinaço e o foguetaço de Bolsonaro (O Globo, 17/9/2018)

12) Em Londres, brasileiros fazem ‘sambaço' e ‘estouro de carro' a favor de Bolsonaro e atraem curiosos (Portal do Holanda, 30/9/2018).

13) Manifestantes sorocabanos se reuniram na manhã deste domingo (30) no Paço Municipal em um ato a favor do candidato à Presidência Jair Bolsonaro (PSL). Segundo os organizadores, participaram jovens, adultos, crianças e idosos. O evento teve bandeiraço, distribuição de adesivos e carro de som. Conforme o evento no Facebook, a organização pedia também aos participantes a doação de um quilo de alimento não perecível. (Jornal Cruzeiro, 30/9/2018).

14.1) Estudantes da Unesp em Marília fazem ‘cadeiraço’ na universidade (G1, 10/5/2016)

14.2) 'Cadeiraço' pede respeito aos direitos das pessoas com deficiência física $(G 1,24 / 9 / 2016))$

Fonte: Elaboração própria.

Um outro valor que pode ser apresentado por substantivos formados a partir do acréscimo de - aço a uma base substantiva é o de ação coletiva. Note-se que, nesse caso, a ideia de grau aumentativo passa a ser representada metonimicamente pela de quantidade do elemento apresentado no radical. Trata-se de ações de grandes proporções que, para assim se constituírem, dependem da participação de muitas pessoas que, por sua vez, devem executar simultaneamente alguma ação específica. Casamentaço (exemplo 1), por exemplo, é a designação atribuída ao casamento comunitário e coletivo realizado por uma ONG para que 1200 pessoas sem condições financeiras pudessem oficializar, perante a lei e a igreja, seus relacionamentos. A grandiosidade do evento, portanto, está associada nesse caso à quantidade de casamentos realizados simultaneamente.

Esses nomes ocorrem, no corpus analisado, sobretudo em orações materiais, mas também em orações relacionais e existenciais, como pode ser observado a seguir: 
1) Orações materiais

1.1 Ator

3. Atividades de 'mamaço' fecham ações do Agosto Dourado no Centro-Oeste Paulista.

14.2 'Cadeiraço’ pede respeito aos diretos das pessoas com deficiência física.

1.2 Meta

2. (...) uma equipe da Diocese da capital realiza adesivaço e venda de artigos religiosos em frente à Catedral de São José, no Centro.

5. Internautas fazem 'vomitaço' contra Temer e PMDB nas redes sociais.

6.2 O PT fará um "tuitaço” com a hashtag \#HaddadÉLula.

8.1 (...) o Meu Rio lançou o Compartilhaço.

8.2 \#DemocraciaSim suspende compartilhaço após ataque de hackers.

9. Universitários fazem 'beijaço' contra suposto ato de homofobia na frente de bar em Boa Vista.

12. Em Londres, brasileiros fazem 'sambaço' e 'estouro de carro' a favor de Bolsonaro.

14.1 Estudantes da Unesp em Marília fazem 'cadeiraço' na universidade.

1.3 Afetado

4. 'Toplessaço' recebe apoio de banhistas na praia de Ipanema.

2) Orações relacionais

2.1. Orações relacionais possessivas

2.1.1 Possuidor

6.1 Decreto é alvo de 'twitaço' [entenda-se: $\mathrm{O}$ twitaço tem um alvo - o decreto].

2.2.2 Possuído

7. Metrô Botafogo, no Rio de Janeiro, recebe mais um "lulaço" (o verbo receber poderia ser substituído por tem).

10. Festa de réveillon de Copacabana terá 'abraçaço' para 2018.

13. O evento teve bandeiraço, distribuição de adesivos e carro de som.

\subsubsection{Circunstância}

1. (...) outras centenas de apaixonados terão a oportunidade de trocar alianças, sem qualquer custo, na edição deste ano do "casamentaço".

3) Orações existenciais

\subsection{Existente}

6.3 No Twitter, há um "twittaço" marcado para as $18 \mathrm{~h}$ com a hashtag \#ConceicaoEvaristoNaABL.

11. [Ocorreu] O panelaço, o buzinaço e o foguetaço de Bolsonaro ${ }^{13}$.

13 Por ser uma frase nominal, entendemos que a notícia visa informar a ocorrência do evento. 
Nas orações materiais, os itens neológicos podem funcionar ou participar de grupos nominais que funcionam como ator, beneficiário ou meta, sendo esta última predominante. As orações relacionais em que comparecem são do tipo possessiva e nelas exercem a função de possuidor, possuído e circunstância. Já nas orações existenciais, exercem a função de termo existente. Além disso, as formas neológicas podem também, embora mais raramente, integrar um grupo preposicional que caracteriza o núcleo, como ocorre em 1, 3 e 6.1 .

Notemos ainda que, mesmo quando integram os sujeitos gramaticais de orações materiais e funcionam como ator, esses itens não fazem referência aos agentes das ações propriamente ditos: em 3), porque mamaço integra o grupo preposicional que caracteriza o núcleo atividades, que, por sua vez, são desenvolvidas pelo grupo de mulheres e homens simpatizantes que encorpam o movimento, e em 14.2), porque cadeiraço refere-se à quantidade de cadeiras de rodas mobilizadas na manifestação, designando metonimicamente as pessoas cadeirantes (ou simpatizantes com a causa) que dela participam. São essas pessoas que pedem respeito, de modo que o evento em si é resultado da sua ação coletiva.

Em nosso entender, a diluição desse traço indicativo de controle do ator sobre a ação deve-se às características prototípicas desse participante, que é normalmente identificado como um ente animado desencadeador de uma ação. Nos exemplos analisados, as formas neológicas não se referem diretamente às pessoas, mas à ação desenvolvida simultânea e anonimamente por elas. O que está em questão é o movimento coletivo, o que implica, portanto, que ninguém se destaque individualmente como responsável. Esse esvaziamento semântico do traço indicativo de controle das formas neológicas pode ser percebido também, no que concerne à metafunção textual, na sua tendência à não topicalização. Como podemos observar no quadro 4, os neologismos em -aço comparecem predominantemente no rema, figurando no tema de apenas três das dezenove ocorrências analisadas.

Já em 4) o verbo receber é ergativo e, por isso, atribui passividade ao sujeito gramatical Toplessaço. Tem-se, assim, uma construção medial em que receber funciona como correlato semântico (PERINI, 2008) do verbo-suporte dar na voz ativa, de modo que a oração poderia ser parafraseada por Banhistas dão apoio a toplessaço, como podemos observar em:

$$
\begin{array}{ccc}
\text { Voz ativa } & \text { Banhistas dão apoio a toplessaço. } & \text { Dar }=\text { verbo-suporte transitivo } \\
\text { Voz média } & \text { Toplessaço recebe apoio de banhistas. } & \text { Receber }=\text { verbo ergativo }
\end{array}
$$

$\mathrm{Na}$ voz ativa, Banhista funciona como ator do processo material expresso pelo verbo-suporte transitivo dar e, na voz média, como fonte que desencadeia o processo que leva um outro participante a receber apoio. Apoio, por sua vez, funciona, na primeira construção, como escopo-processo, isto é, como um complemento que forma com o verbo-suporte um significado global que pode ser traduzido por apoiar e, na segunda, 
como meta da ação de receber. Já toplessaço funciona como beneficiário-recebedor na oração com dar e como afetado na oração com receber. Deve-se ressaltar, porém, que, também nesse caso, a construção neológica refere-se ao movimento organizado por uma coletividade, e não à coletividade em si, que é constituída pelas pessoas que participam da manifestação e que, portanto, receberam apoio dos banhistas.

Do ponto de vista semântico, é possível observar ainda algumas distinções em relação aos neologismos encontrados no corpus. Em casamentaço (exemplo 1), como vimos, temos apenas o sentido de ação coletiva. Do exemplo 2 ao 12, entretanto, essa ação ganha uma especificação. Isso porque os substantivos criados nomeiam manifestações coletivas realizadas em prol de uma causa social e/ou para reivindicação de algo. Deve-se ressaltar que, apesar de esse valor ser citado apenas por Sandmann (1987, 1991) e não comparecer nas demais gramáticas e manuais consultados, já existem duas palavras legitimadas no português brasileiro que, inclusive, comparecem no exemplo 10. São elas: buzinaço, que é registrada pelo VOLP e pelo Dicionário Houaiss com o sentido de "manifestação a favor ou contra alguma coisa feita com sons de buzinas"14 e panelaço, que é registrada por esse mesmo dicionário com o sentido de "manifestação popular coletiva de protesto que consiste em fazer grande ruído percutindo [...] utensílios metálicos numa hora determinada" ${ }^{15}$.

O substantivo buzinaço tem origem controversa e, segundo Santos (2010), foi registrado por um dicionário brasileiro pela primeira vez em 1985. Para Sandmann (1987), nesse item lexical o significado de golpe ou pancada foi substituído pelo de toque, sopro, e seu surgimento está relacionado às emissões televisivas do programa do Chacrinha. $\mathrm{O}$ autor acrescenta ainda que, seguindo o modelo de buzinaço, foram criados à época outros dois neologismos: "apitaço [...], 'manifestação ruidosa com apitos', e panelaço. 'manifestação ruidosa com panelas', provavelmente um empréstimo do espanhol” (SANDMANN, 1987, p. 59). Em publicação de 1991, Sandmann considera esse deslocamento de sentido como um processo de deriva semântica, embora em nenhuma das publicações explique como de toque, sopro o sufixo -aço teria passado a designar um tipo de manifestação. Sabemos, contudo, que, com esse sentido, é registrado pela mídia brasileira pelo menos desde 2010, sendo empregado para designar a manifestação realizada, sobretudo por taxistas, por caminhoneiros, como ocorreu durante a greve de 2018, por motoristas de ônibus e, mais recentemente, de Uber, para reivindicar direitos e benefícios. Do ano de 2015 a 2018, devido à polarização que assola o país, esse termo vem sendo utilizado também em manifestações políticas, especialmente, mas não só, naquelas organizadas pela direita contra o Partido dos Trabalhadores (PT), a favor do impedimento da presidenta Dilma Rousseff (PT), ocorrido em 2016, e, nas eleições presidenciais de 2018, pró o candidato da extrema direita Jair Bolsonaro.

\footnotetext{
14 “buzinaço". Disponível em: https://houaiss.uol.com.br/pub/apps/www/v3-3/html/index.php\#2. Acesso em: 5/10/2018. 15 "panelaço". Disponível em: https://houaiss.uol.com.br/pub/apps/www/v3-3/html/index.php\#3. Acesso em: 5/10/2018.
} 
Já panelaço é, segundo Alves (2006), oriundo do espanhol cacerolazo, empregado pela primeira vez em 1971 no Chile em uma marcha de membros da classe média e alta contrários ao governo socialista de Salvador Allende. O vocábulo, também utilizado na Argentina em 2001 nas manifestações contra o presidente De La Rua (AVRITZER, $2015)^{16}$ e, posteriormente, no Uruguai e na Venezuela (SANTOS, 2010), é formado a partir do acréscimo ao substantivo cacerola (do esp., panela) do sufixo -azo, que, dentre outros sentidos, expressa em espanhol o de golpe ou pancada com algo, equivalendo ao sufixo português -ada, presente, por exemplo, em cabeçada (em esp., cabezazo). Assim sendo, conforme Alves (2006, p. 136), o vocábulo cacelorazo foi criado, para nomear, o protesto chileno porque os manifestantes ficavam "batendo panelas para provocar ruído forte". Já, no português brasileiro, ainda em conformidade com a autora, foi primeiramente decalcado, isto é, adaptado literalmente do espanhol para o português, sob a forma caçarolaço (caçarola +aço), sendo a palavra base substituída logo depois por panela, devido ao fato de ser o seu emprego no Brasil mais comum que o de caçarola, para denotar o significado de "ação repetitiva e barulhenta" (ALVES, 2006, p. 137).

Em 2013, o termo panelaço passou a circular nas manifestações que foram realizadas em diversas cidades brasileiras contra o aumento de $\mathrm{R} \$ 0,20$ da passagem de ônibus e, em 2014, nas manifestações contra a realização da Copa do Mundo, ganhando maior projeção em 2015 e 2016 nas manifestações a favor do impedimento da presidenta Dilma. Em 2016 e 2017, esse tipo de protesto também foi realizado contra o então presidente Michel Temer, ex-vice de Dilma Rousseff, voltando a ser empregado, em 2018, no âmbito das eleições presidenciais, em manifestações a favor da prisão do ex-presidente Luís Inácio Lula da Silva e, posteriormente, contra a sua libertação para evitar que concorresse ao cargo de presidente, bem como em protestos a favor do candidato da extrema direita.

No que tange à natureza do significado de - $a$ ço enquanto ação/manifestação, faz-se ainda preciso tecer alguns comentários. De acordo com Santos (2010), é o significado de golpe - e não o de manifestação - que não é próprio do português. Para a autora, esse significado seria oriundo da analogia feita em relação a palavras originalmente do espanhol que foram decalcadas para o português. Ainda conforme Santos (2010, p. 153), "a alta produtividade de uma dessas palavras pode ter contribuído para as formações com valor de golpe em português" e, diferentemente do que afirmam Alves (2006) e Sandmann $(1987,1991)$, consequentemente, também para a formação de palavras com o sentido de ação/manifestação, como panelaço e buzinaço. Santos (2010) destaca ainda que, nesse caso, a produtividade não deve ser atribuída ao sufixo, mas à recorrência de uma palavra decalcada.

Há ainda quem, como Souza (2015), relacione o sentido de manifestação não ao de ação, mas ao de conjunto. Sandmann (1987, p. 59), no entanto, sem negar a relação com a língua espanhola, considera que, seja qual for o sentido, "a ideia de 'intensidade'

16 Artese e Braga (2015) apontam o final da década 1960 e o início da década de 1970 como o momento de surgimento na Argentina de denominações de manifestações como o sufixo -azo (Cordobazos em 1969-1971, Rosariazo em 1969 , Tucumanazos em 1970-1972, Mendozazo em 1972 etc.). 
ou 'tamanho' está sempre presente: barcaça 'barca grande', mulheraço 'mulher grande' ou 'mulher muito atraente', pataço 'golpe forte com a pata', apitaço 'manifestação ruidosa com apitos"”. Para justificar esse seu posicionamento, ele observa, a partir de Gauger, que, em língua portuguesa, assim como em espanhol, há dois sufixos -aço, embora naquela essa distinção seja menos produtiva devido à influência de um sobre o outro. Afirma o autor:

Gauger (1968, p. 93s) vê no espanhol martillazo dois homônimos: martillazo I 'martelo grande' e martillazo II 'golpe com o martelo. Homônimos, como diz, são em si -azo I 'grande' e -azo II 'golpe'. Paralelamente a isso pode-se falar em português em -aço I (caçarolaço 'caçarola grande') e -aço II (joelhaço 'golpe forte com o joelho'). Acontece, porém, que no português as formações em -aço II assumem também a significação de -aço I: pataço não é, como patada, simplesmente 'golpe com a pata', porém 'golpe violento com a pata'. Em outras palavras, -aço I influenciou -aço II, transmitindo-lhe seu significado. (SANDMANN, 1988, p. 34, negrito do autor).

Para nós, todavia, assim como pontuamos anteriormente, embora não neguemos a existência de uma relação diacrônica entre o sentido de golpe e o de ação/manifestação, o que se destaca sincronicamente - e que inclusive engloba as ideias de conjunto, intensidade e tamanho - é a relação metonímica entre a grandiosidade do evento e a quantidade das entidades identificadas pelo radical da palavra base - relação essa que se faz presente inclusive na definição de Sandmann de apitaço a partir do emprego de apitos na sua forma plural e que justifica, portanto, do ponto de vista sincrônico, a consideração, tal como propõe Monteiro (2002), da significação de -aço enquanto um caso de polissemia e não de homonímia. Desse modo, entendemos que, para se fazer um apitaço é necessário que haja muitas pessoas apitando ao mesmo tempo - e, para isso, deve haver muitos apitos -; para se fazer um buzinaço, é preciso que haja muitas pessoas soando buzinas ao mesmo tempo e, portanto, muitas buzinas; e, para que haja um panelaço, é preciso que haja muitas pessoas batendo em panelas ao mesmo tempo e, portanto, muitas panelas. Além disso, como pontuamos inicialmente, faz-se preciso destacar que, apesar de haver uma relação semântica muito próxima entre os significados de ação e manifestação, estes diferem em função da finalidade das ações desenvolvidas.

Por fim, lembremos ainda que, conforme pontuou Azeredo (2008), um ato de criatividade irregular - a saber, o decalque de uma palavra do espanhol para o português brasileiro com um significado ainda não previsto na língua receptora, seja qual for esse significado - pode gerar um modelo produtivo e regular que, como ressaltou Câmara Jr. (1975), orientará a estruturação de novas palavras. Assim sendo, entendemos, com esses autores, que, após a naturalização do(s) significado(s) da(s) palavra(s) formadas por - aço originalmente decalcada(s) do espanhol, houve o apagamento do processo analógico, de modo que - diferentemente do que defende Santos (2010) - passou/ 
passaram a ser atribuídos não à(s) palavra(s) decalcada(s), mas ao sufixo, possibilitando, dessa maneira, como veremos adiante, a criação de novas palavras sem que fosse necessário se recorrer ao modelo daquela(s) originalmente decalcada(s) do espanhol.

Dito isso, voltemos à análise dos neologismos criados contemporaneamente com sufixo - aço presentes no Quadro 4. A partir do exemplo 2, como dissemos, as formas neológicas passam a designar manifestações. Dentre elas, as mais antigas a que tivemos acesso por meio da pesquisa em veículos de comunicação digitais são cadeiraço (exemplos 14.1 e 14.2) e toplessaço (exemplo 4). Formado a partir do acréscimo do sufixo -aço ao radical de cadeira, cadeiraço foi empregado, a partir de 2010, para designar a manifestação realizada por cadeirantes para reivindicar respeito às pessoas com deficiência física (exemplo 14.2). A partir de 2016, porém, passou a designar também o protesto de alunos da UNESP contra o corte de repasse de verba no qual cadeiras foram colocadas para impedir a passagem de outros alunos para as salas de aula (exemplo 14.1). Em ambos os casos, a grandiosidade do evento está associada ao número de cadeiras (de rodas ou escolares) presentes. Já toplessaço é neologismo morfológico formado por meio do acréscimo do sufixo -aço à expressão oriunda do inglês topless e incorporada ao léxico do português com sua grafia original com a seguinte acepção, segundo o Dicionário Houaiss: "indumentária feminina que não cobre o corpo da cintura para cima" ${ }^{17}$. Os primeiros registros desse vocábulo na mídia brasileira datam de 2013, sendo empregado recorrentemente em 2014, 2015, 2016 e 2017 para designar as manifestações realizadas em prol da promoção do debate sobre a não criminalização da nudez feminina e pelo término da repressão policial sobre os corpos das mulheres.

Também utilizados em prol de causas sociais encontramos, a partir de 2017 , beijaço e abraçaço formados a partir do acréscimo do sufixo -aço aos substantivos beijo (exemplo 9) e abraço (exemplo 10), respectivamente. O primeiro neologismo foi empregado sobretudo em prol de causas LGBTs; já o segundo foi empregado em diferentes contextos, tais quais: em manifestações em prol dos direitos das mulheres e de pessoas com deficiência, pela paz, pela revitalização de centros culturais e contra a violência na comunidade da Maré (RJ) após a morte de um estudante de 13 anos por policiais em 2018. No que diz respeito ao primeiro neologismo - beijaço -, deve-se pontuar ainda que, a depender do contexto empregado, ele também pode apresentar diferentes sentidos, como ocorre na seguinte manchete: "O Tempo Não Para: Samuca dá beijaço e quase transa com Marocas" (Uol, notícias da TV, 20/8/2018). Nesse caso, o sufixo -aço manifesta modalidade, acrescentando ao radical a que se agrega um juízo de valor - o beijo entre os personagens da novela "O tempo não para" (Rede Globo em 2018) é considerado um beijo intenso, apaixonado, demorado etc.

Já em adesivaço (exemplo 2), a ação de comprar o adesivo do Círio de Nazaré e de colá-lo nos automóveis tem por objetivo arrecadar fundos para o tradicional festejo da igreja católica. Logo, quanto mais adesivos houver nos carros, maior será o movimento.

17 “topless". Disponível em: https://houaiss.uol.com.br/pub/apps/www/v3-3/html/index.php\#7. Acesso em 5/10/2018. 
Em mamaço, a ação desenvolvida por mães ao amamentarem simultaneamente seus bebês tem por objetivo estimular a alimentação desses com o leite materno. A grandiosidade do movimento dependente, portanto, de que haja um número significativo de mães amamentando seus bebês no dia e local marcado.

O advento das redes sociais e a sua popularização no Brasil também contribuíram para o surgimento de manifestações virtuais. Esse é o caso de vomitaço (exemplo 5), tuitaço (exemplos 6.1, 6.2 e 6.3) e compartilhaço (exemplo 8.3). As publicações mais antigas dos dois primeiros datam de 2016. O vomitaço foi a manifestação coletiva realizada por opositores ao impedimento da presidenta Dilma Rousseff e à assunção do seu vice Michel Temer por meio da publicação do "emoji vomitando" nas páginas das redes sociais do PMDB - partido de Temer.

Tuitaço, por sua vez, foi empregado com diferentes grafias sempre com o sentido de compartilhamento coletivo de frases com hashtags em prol de uma determinada causa no Twitter - forma verbal oriunda do inglês que nomeia uma rede social e cuja tradução literal seria gorjear, cantar (do pássaro). Ao nomear uma rede social, a unidade léxica, originalmente derivada do verbo onomatopaico tweet, que se refere ao som do canto do pássaro, equivalendo ao verbo piar no português, é substantivada, servindo de base para a formação do neologismo com o sufixo - aço, o qual comparece nos veículos midiáticos grafado das seguintes formas: 1) mantendo a grafia original do radical (twittaço, exemplo 6.3), 2) adaptando parcialmente a grafia original do radical a partir da eliminação das letras geminadas (twitaço, exemplo 6.1) e 3) com a grafia totalmente adaptada (tuitaço, exemplo 6.2). As causas em prol das quais são realizados os tuitaços são diversas, tais como: demonstração de descontentamento e reivindicação de medidas em relação ao desastre de Mariana em 2015, reivindicação dos direitos dos LGBTs, oposição ao decreto que derruba a obrigação de rotulagem de transgênicos, à lei de terceirização do trabalho e ao golpe político colocado em curso a partir de 2015, defesa da candidatura da escritora Conceição Evaristo a uma cadeira da ABL e, em 2018, em prol de candidatos a cargos governamentais em diferentes esferas.

Já compartilhaço, além da acepção de compartilhamento coletivo de algo nas redes sociais, também apresenta duas outras acepções: 1) é o nome de um aplicativo que promove a sincronização de milhares de páginas para fazer a divulgação de causas públicas e importantes (exemplo 8.1) e 2) designa uma das ações da campanha "Favela 3D - Disposição, Diversidade e Direitos", elaborada pelos alunos da Escola Popular de Comunicação Crítica (ESPOCC), do projeto do Observatório de Favelas, que consiste em expor em passarelas da Avenida Brasil (RJ) várias frases adaptadas da Declaração dos Direitos Humanos com o objetivo de romper estereótipos e mostrar a favela como lugar de potência e diversidade. Nesse sentido, é a quantidade de frases dispostas nas passarelas que promove a grandiosidade da ação.

O contexto político engendrado pelas eleições de 2018 fez surgir ainda outros neologismos, tais como: 
1. Lulaço (exemplo 7): manifestação em prol da libertação de Lula e pela aceitação da sua candidatura a presidente;

2. Foguetaço (exemplo 11): manifestação em prol de um candidato na qual são soltos diversos fogos de artifício;

3. Sambaço (exemplo 12): manifestação em prol de um candidato na qual vários manifestantes cantam, tocam e dançam ao som do ritmo samba; e

4. Bandeiraço (exemplo 13): manifestação em prol de um candidato na qual os manifestantes em passeata carregam bandeiras partidárias.

Esse último também comparece no corpus analisado expressando modalidade com o sentido de bandeira grande, como podemos ver em:

O impressionante bandeiraço do Corinthians. Na prévia da semifinal da Copa do Brasil contra o Flamengo, o Timão realizou um treinamento aberto. Cerca de 38 mil presentes no Allianz Park [Parque] para incentivar os jogadores", contou o jornal, em sua manchete. ${ }^{18}$

Note-se ainda que em 1) e 3), diferentemente do que ocorre nos demais neologismos que nomeiam manifestações, não observamos a relação metonímica sobre a qual discorremos anteriormente - fato que comprova a naturalização do sentido de manifestação associado ao sufixo -aço e a sua produtividade. Em 1), o radical refere-se àquele em prol de quem se manifesta - o ex-presidente Lula; e, em 3), ao ritmo que embalará a manifestação - o samba. Essa quebra de paradigma também já havia sido observada por Sandmann (1991, p. 55) ao analisar as unidades léxicas academaço e quartelaço. Segundo o autor, a primeira foi criada em 1987 em referência à manifestação ruidosa contra a comitiva do ex-presidente Sarney nas proximidades da Academia Brasileira de Letras e a segunda, no mesmo ano, em referência à manifestação militar que ocorreu na Argentina durante a Semana Santa. Em ambos os casos, observa-se - diz Sandmann - que "o elemento 'lugar' foi acrescentado como ingrediente do significado da formação nova". Tem-se, assim, tal como observamos em 1) e 3), uma neutralização de restrições à regra em questão na formação de unidades com - aço que se manifesta por meio da substituição da relação metonímia, nesse caso, pela ideia de lugar: academaço é a manifestação que ocorre na Academia e quartelaço a manifestação que ocorre no quartel; e em 1) e 3), como dissemos, pelo nome em prol daquele que se manifesta e pelo ritmo que embala a manifestação, respectivamente.

18 Disponível em: https://www.espn.com.br/futebol/artigo/_id/4801778/corinthians-treino-aberto-vai-parar-em-jornalargentino. Acesso em: 12 mar. 2021. 


\section{Empréstimo linguístico e neologismo semântico}

Quadro 4 - Neologismos formados a partir de bases substantivas (derrota metafórica)

1) Brasil é derrotado pelo Uruguai no ‘Maracanazo' em 1950 (Estadão, 11/5/2018)
2) Ilusão do título, Maracanaço colorado e Lomba paredão: os memes da vitória do Inter sobre
o Fluminense (Zero hora, 13/8/2018)
$\begin{aligned} & \text { 3) Veja os melhores momentos dos 'Maracanaço' do Independiente sobre o Flamengo (Fox } \\ & \text { Sports, } 13 / 12 / 2017 \text { ) }\end{aligned}$

Fonte: Elaboração própria.

Assim como panelaço, a forma neológica maracanazo é oriunda do espanhol e surgiu na década 1950 para nomear a derrota na final da Copa do Mundo por 2X1 da seleção brasileira para o Uruguai no estádio Maracanã, conforme observamos no exemplo 1 uma reportagem histórica do jornal Estadão na qual a palavra comparece com sua grafia original entre aspas. Lembremos aqui que, em espanhol, o sufixo -azo denota, dentre outros significados, o de golpe ou pancada. Assim sendo, entendemos que, derivando desse significado, o termo em espanhol passou a designar, metaforicamente, um golpe ou pancada dada pela seleção uruguaia na seleção brasileira no Maracanã na final da Copa do Mundo e foi utilizado no Brasil à época com sua grafia original. É possível que essa tenha sido, portanto, a primeira palavra de origem espanhola com o sufixo -azo significando golpe, ainda que metaforicamente, a ser emprestada para o português brasileiro. Ocorre, porém, que, como atestam os exemplos 2 e 3, contemporaneamente, no Brasil, a palavra não só teve a sua grafia adaptada ao português, como, devido ao seu processo de lexicalização e, por conseguinte, de mais uma deriva semântica, passou por uma ampliação de sentido, deixando de designar apenas a histórica derrota do Brasil para o Uruguai no Maracanã na final do campeonato mundial de 1950, mas qualquer derrota sofrida em finais por um time brasileiro no Maracanã.

Notemos ainda que, neste caso, tal como pontuou Sandmann (1991) em relação a academaço e quartelaço, há a associação do sufixo -aço com o sentido metafórico de golpe a uma base que designa lugar, e não o instrumento/parte do corpo com o qual se dá um golpe (forte, violento), como ocorre em chifraço, canivetaço, pataço e joelhaço, em português, e palazo, martillazo e cabezazo, em espanhol.

\section{-aço como metáfora gramatical}

Em LSF, o termo metáfora gramatical é empregado em referência "ao uso de um recurso gramatical para exprimir uma função que não lhe é intrínseca" (SARDINHA, 2007 , p. 45). Sob essa perspectiva, há no sistema linguístico uma estrutura congruente, isto é, primária ou não marcada, de realização direta que, quando metaforizada, passa 
a ter uma realização indireta, de modo que outros recursos gramaticais passam a ser empregados para exprimir o mesmo sentido.

Há dois tipos de metáfora gramatical: a interpessoal e a ideacional. A primeira ocorre quando não são utilizados recursos congruentes para expressar modo ou modalidade. Foi o que observamos anteriormente, ao analisarmos o funcionamento do sufixo -aço para expressar intensidade e juízo de valor, quando agregado, respectivamente, a bases adjetivas e substantivas, e por isso não nos deteremos a ela aqui. Já a segunda ocorre quando um elemento linguístico adquire um novo sentido, seja no estrato fonológico/grafológico, léxico-gramatical ou semântico-discursivo. Pode-se dizer que a realização direta é regida pela harmonia, havendo um sentido específico para cada elemento linguístico. A atribuição de um novo sentido a um elemento implica, portanto, a desarmonia do sistema, gerando uma tensão entre os diferentes estratos da qual decorre a metáfora gramatical.

A análise das formas neológicas formadas por - $a$ ço, produzidas a partir de elementos mórficos do português brasileiro ou por empréstimo do espanhol atestam a produtividade desse sufixo - produtividade esta observada tanto no que respeita ao aspecto formal quanto ao semântico. No tocante especificamente aos substantivos que denotam ação coletiva e manifestação, constatamos, como vimos, dois efeitos do processo de lexicalização do sufixo -aço no português brasileiro: 1) a deriva semântica de golpe, pancada para toque e, em seguida, para ação/manifestação; e 2) a possibilidade de substituição da relação metonímica expressa pelo primeiro elemento da unidade léxica por outras relações de sentido. Embora o primeiro ponto também se refira a uma metáfora gramatical estabelecida no estrato semântico-discursivo, já que se originou de uma tensão no sistema a partir da qual, como vimos, foi criado um modelo produtivo que passou a servir de base para a formação de novas palavras, como essa questão já foi devidamente abordada nas seções anteriores, interessa-nos aqui descrever o funcionamento da metáfora que, a nosso ver, implica o segundo ponto.

Conforme Sandmann (1988), os sufixos não só não são vazios de significado, como alguns gramáticos e linguistas costumam afirmar, como por vezes podem corresponder semanticamente a lexemas. Nesse sentido, defende o autor que, tal como afirma Gauger em relação ao funcionamento do sufixo -azo II, que, como vimos, significa golpe, nos substantivos portugueses em que - aço expressa ação coletiva, manifestação e - nós incluímos - derrota (golpe metafórico ${ }^{19}$ ), o sufixo não é um acessório do radical, como ocorre, por exemplo, em festaço, em que -aço, ao expressar um julgamento de

19 Como não estabelece tensão no sistema gerando um modelo produtivo - lembremos que essa é a única palavra com -aço com o sentido de derrota que conhecemos em português brasileiro -, a metáfora a que nos referimos aqui não se configura (ainda) como uma metáfora gramatical. Em outras palavras, trata-se de um ato criativo que ainda não se tornou e talvez não se torne regular no sistema. Assim, metáfora é nesse momento empregado no seu sentido mais tradicional, isto é, enquanto figura de linguagem que estabelece uma espécie de comparação implícita - uma derrota é um golpe; logo, maracanaço é uma derrota sofrida no estádio Maracanã. O interessante é, contudo, observar que essa metáfora é estabelecida não pela palavra em si, mas pela significação no sufixo -aço enquanto golpe na sua relação com a situação comunicativa em que o item lexical foi produzido. O sentido de derrota configura-se, assim, como um valor ilocutório (BECHARA, 2009) atribuído ao sufixo em função da determinação sofrida pelos fatores contextuais. 
valor melhorativo, configura-se como um atributo de festa, ou em perdidaço, em que intensifica a ideia expressa pelo adjetivo. Em formações como casamentaço, beijaço e maracanaço, o que está em questão não é o significado expresso pelo primeiro elemento mórfico, mas, respectivamente, a ação coletiva, a manifestação e a derrota.

Há, pois, decorrente da lexicalização desse morfema no português, uma inversão em relação à ordem em que comparece o elemento de significação mais relevante na unidade léxica, de modo que casamento, beijo e maracanã passam a funcionar como elementos acessórios de - aço, cujo sentido lhes é, portanto, anterior, visto que expressa a informação mais importante do todo, que, como vimos, pode ser inclusive parafraseado por grupos sintáticos complexos, como em: ação coletiva em que vários casamentos ocorrem ao mesmo tempo, manifestação em prol de uma determinada causa em que várias pessoas se beijam ao mesmo tempo, derrota que ocorre no maracanã.

Daí considerarmos que essa inversão da função desempenhada pelos morfemas que constituem as formações neológicas com - aço que designam ação, manifestação ou derrota configura-se como o resultado de um processo de metaforização, que, por sua vez, estabeleceu uma tensão no estrato léxico-gramatical do sistema linguístico. É, pois, nesse sentido, que entendemos ser a significação de -aço como lexema - e, portanto, como elemento de maior relevância semântica do item lexical - o que possibilita a neutralização da restrição mencionada anteriormente que se colocava em relação à significação do primeiro elemento das formas neológicas, possibilitando a sua substituição por elementos que evocam outras relações de sentido, como ocorre em academaço, quartelaço, lulaço e sambaço.

\section{Conclusões}

Neste artigo, após fazer um levantamento da literatura linguístico-gramatical referente às formas derivadas a partir do acréscimo do sufixo - aço a bases nominais, propomo-nos a descrever o funcionamento de neologismos recentes em circulação na mídia digital a partir da ótica da LSF. Nesse sentido, observamos primeiramente, com Azeredo (2008), que o surgimento de um neologismo está associado a um critério de utilidade e necessidade de emprego. Os itens lexicais em -aço produzidos contemporaneamente e em circulação na mídia brasileira foram criados, como vimos, com o fito de intensificar características atribuídas aos participantes situacionais e/ou textuais, para expressar um juízo de valor da parte de um dado participante ou nomear uma ação coletiva, manifestação ou derrota.

No que concerne aos dois primeiros propósitos interacionais, vimos que o acréscimo de -aço com esses valores respectivamente a bases adjetivas e substantivas configurase como uma metáfora gramatical interpessoal a partir da qual esse morfema passa a funcionar como um recurso gramatical que manifesta modalidade, expressando a opinião, ponto de vista ou julgamento de um dado participante. Já no que respeita ao terceiro propósito, observamos a ocorrência de duas metáforas gramaticais ideacionais - 
a primeira estabelecida no estrato semântico-discursivo a partir do processo de deriva semântica (de golpe/pancada a ação/manifestação); e a segunda, no estrato léxicogramatical, a partir da significação de -aço como lexema.

Cabe ressaltar que todos esses processos de metaforização de - $a c ̧ o$ estabelecidos no sistema linguístico são sintomas, como podemos depreender a partir de Sandmann (1991), da sua perfeita integração ao léxico do português brasileiro. É, pois, a lexicalização desse morfema que possibilita que passe por um processo de desmotivação - desassociação em relação a sentidos primários - seguida de deriva semântica - atribuição de novos sentidos -, de modo que um ato inicialmente criativo e irregular torna-se um modelo produtivo que passa a servir de base para a formação de outras palavras (AZEREDO, 2008; CÂMARA JR., 1975). Essa deriva, porém, embora passe despercebida ao falante comum dando-lhe a impressão de ser totalmente desmotivada, está submetida inicialmente a processos analógicos, havendo, assim, no caso de - $a c ̧ o$, uma desmotivação apenas relativa - panelaço passa a nomear uma manifestação em que se bate (golpeia) em panelas; a atenuação do sentido de golpe para toque permite a criação de buzinaço, no sentido de tocar buzinas, que posteriormente deriva para manifestação em que se tocam buzinas; e a percepção de uma derrota enquanto um golpe sentido emocionalmente pelos torcedores da seleção brasileira permite a criação de maracanaço.

Uma vez que a criação de um neologismo está associada a um critério de utilidade, devemos considerar ainda a determinação da deriva semântica por fatores históricos e contextuais. Como vimos, a popularização da ocorrência de manifestações no Brasil fatos históricos - exerce influência sobre a frequência de emprego de palavras como buzinaço e panelaço, tomando-as inicialmente como modelo para criação de novas designações. Tal frequência é também a responsável pela naturalização desse afixo no PB com o sentido de manifestação, que, como vimos, provavelmente é oriundo do espanhol. Entretanto, como no sistema linguístico do PB o sufixo -aço já existia com outros significados, tem-se a convergência de vários significados em apenas uma forma, que passa então a ter nesse sistema linguístico um uso polissêmico.

Por último, devemos destacar ainda dois aspectos em relação ao funcionamento dos nomes de ação/manifestação presentes nas notícias analisadas: 1) a diluição do traço indicativo de controle por parte do ator em função das características prototípicas desse participante que se faz significar ainda na tendência a não topicalização desses nomes e na sua figuração como termo paciente em construções ergativas; e 2) a manutenção da noção de dimensão a partir do estabelecimento de uma relação metonímica entre a grandiosidade do evento e a quantidade de entidades identificadas pelo primeiro elemento do item lexical - regra esta que, todavia, em função da lexicalização do sufixo - aço, como vimos, foi neutralizada na formação de alguns neologismos, como lulaço e sambaço. 
SCHLEE, M.; COSTA, T. Neologisms with -aço suffix in Brazilian Portuguese: a functional perspective. Alfa, São Paulo, v.65, 2021.

- ABSTRACT: In the light of a theoretical framework based on systemic-functional linguistics $(S F L)$, the present article aims at investigating the process of formation of contemporary neologisms in Brazilian Portuguese by the addition of the suffix - aço to nominal bases, whether or not they are Portuguese. . The corpus analized is comprised of digital news articles, obtained from Brazilian online publications, such as, newspapers and, published between 2016 and 2018. With this proposal in mind, a brief review of literature is presented in an attempt to illustrate the rationale underlying the use of and semantic values ascribed to the suffix in questions in grammar books and textbooks on linguistics. This description was carried out in order to verify whether the current uses of this affix are in accordance with those found in specialised compendia. The analysis allowed not only for the verification of the polysemic functioning of the affix, but also, in certain circumstances, for its metaphorisation due to the tension established in different linguistic strata, be it in the interpersonal metafunction, or in the ideational metafunction stances.

- KEYWORDS: Systemic-Functional Linguistics. Suffixation. Neologism.

\section{REFERÊNCIAS}

ALVES, I. A observação sistemática da neologia lexical: subsídios para o estudo do léxico. Alfa, São Paulo, v.50, n.2, p.131-144, 2006.

ALVES, I. Neologismo: criação lexical. São Paulo: Ática, 1994.

ARTESE, M.; BRAGA, L. Notas para a caracterização do protesto e do conflito social na história recente da argentina. Revista Despierta, Curitiba, ano 2, n.2, 2015.

AVRITZER, L. O panelaço e as formas do protesto social. 2015. Disponível em: https://www.cartamaior.com.br/?/Editoria/Politica/O-panelaco-e-as-formas-doprotesto-social/4/33657. Acesso em: 5 mar. 2021.

AZEREDO, J. C. Gramática Houaiss da Língua Portuguesa. São Paulo: Publifolha Houaiss, 2008.

BASÍLIO, M. Formação e classes de palavras no português do Brasil. São Paulo: Contexto, 2011.

BECHARA, E. Moderna Gramática Portuguesa. 37. ed. Rio de Janeiro: Lucerna, 2009.

CÂMARA JR., J. M. História e estrutura da língua portuguesa. Rio de Janeiro: Prolivro, 1975. 
CUNHA, C.; CINTRA, L. Nova gramática do português contemporâneo. Rio de Janeiro: Nova Fronteira, 2001.

HALLIDAY, M. A. K.; MATTHIESSEN, C. M. I. Halliday's Introduction to Functional Grammar. 4th. ed. London: New York: Routledge, 2014.

MARONEZE, B.; CARDOSO, E. de A.; PISSOLATO, L. Derivação sufixal. In: RODRIGUES, A.; ALVES, I. M. A construção morfológica da palavra. São Paulo: Contexto, 2015. p. 57-110.

MONTEIRO, J. L. Morfologia Portuguesa. 3 ed. Campinas, SP: Pontes, 2002.

PERINI, M. Estudos de gramática descritiva: as valências verbais. São Paulo: Parábola Editorial, 2008.

ROCHA, L. C de A. Estruturas morfológicas do Português. São Paulo: Martins Fontes, 2008.

SANDMANN, A. J. Competência lexical: produtividade, restrições e bloqueio. Curitiba: Ed. da UFPR, 1991.

SANDMANN, A. J. Formação de palavras no português brasileiro contemporâneo. Curitiba: Scientia et labor: Ícone, 1988.

SANDMANN, A. J. Novidades do "front" da formação de palavras. Letras, Curitiba, v.30, p.54-68, 1987.

SANTOS, A. P. Polissemia dos sufixos aumentativos -ão, -arro, -orro, -aço e -uço e seus traços avaliativos sob a perspectiva diacrônica. 339f. 2010. Dissertação (Mestrado em Letras) - Faculdade de Filosofia, Letras e Ciências Humanas, Universidade de São Paulo, São Paulo, 2010.

SARDINHA, T. B. Metáfora. São Paulo: Parábola, 2007.

SOUZA, L. M. de. O processo de derivação de sufixos aumentativos no português brasileiro: uma análise de -ão, -ona, -aço, -aça, -uço e uça. 119f. 2015. Dissertação (Mestrado em Teoria e Análise Linguística) - Instituto de Letras, Universidade Federal do Rio Grande do Sul, Porto Alegre, 2015.

Recebido em 25 de fevereiro de 2019

Aprovado em 12 de outubro de 2019 